\title{
STRUCTURED PROBLEM SOLVING: COMBINED APPROACH USING 8D AND SIX SIGMA CASE STUDY
}

\author{
Mithun Sharma (i) SHILPI SHARMA* (i) SANJEeV SaHNI
}

\begin{abstract}
A B S T R A C T
The current research study aimed to explore the utility of selected problem-solving tools and techniques in root-cause analysis to demonstrate their practical application. An experimental research design adopting a positivist empirical approach with a deductive strategy was followed to assess the effectiveness of a combined (8D \& Six Sigma) problem-solving approach in reducing a high defects rate of a mixer shower assembly line. A novel application of the 8D framework in combination with Six Sigma and other analytical tools was found highly effective in reducing the reject rate from $11.84 \%$ to $0.11 \%$. Successful identification of the root cause led to the implementation of permanent corrective action ensuring a long-term stable assembly process. The research study provided a problem-solving framework that was found effective in resolving a complex problem and implementing long-term corrective action in an assembly production line. However, this framework can be used in other industries. The research study provides a solution to a high number of leak rejects in a subassembly where "O-seals" are used between mating parts. It also provides analytical tools that were found highly effective during the problem-solving process.
\end{abstract}

KEY WORDS

8D, Six Sigma, Structured Problem Solving, customer complaints, defect reduction

10.2478/emj-2020-0005
Shilpi Sharma

O.P. Jindal Global University, India ORCID 0000-0003-4316-8551

*Corresponding author: e-mail: shilpi@jgu.edu.in

Mithun Sharma

O.P. Jindal Global University, India ORCID 0000-0002-0108-6331

Sanjeev Sahni

O.P. Jindal Global University, India ORCID 0000-0001-7429-8549

\section{INTRODUCTION}

In today's ever-evolving challenging times, the problem-solving skillset is one of the most desired attributes (De Fruyt, Wille \& John, 2015) in any industry. Problem-solving is at the core of human evolution.
It is the method used by humans to understand what is happening in their environment, identify things to be changed and then establish adjustments that are required for achieving the desired outcome. Problemsolving is the source of all new inventions, social and

Citation: Sharma, M., Sharma, S., \& Sahni, S. (2020). Structured Problem Solving: combined approach using 8D and Six Sigma case study. Engineering Management in Production and Services, 12(1), 57-69. doi: 10.2478/emj-2020-0005 
cultural evolution, and the basis for market-based economies. It is the basis for continuous improvement, collaboration and learning. It is, however, well known that stressful circumstances may induce impulsive solution-seeking without gaining adequate insights into the nature of a confronted problem. Based on a survey of $106 \mathrm{C}$-suite executives representing 91 private and public-sector companies in 17 countries, it was found that $85 \%$ of the population sample perceived that their organisation's problem diagnosis skills were bad; and $87 \%$ reported that a failure to identify an accurate problem incurred significant costs (Wedell-Wedellsborg, 2017). One of the prime reasons for an organisations' struggle with problem diagnosis is the lack of time and effort required for a rigorous diagnostic procedure. Many popular existing frameworks, such as Six Sigma, TRIZ, TQM, Scrum, and others, are very comprehensive and directed in terms of complex problem-solving. However, for day-to-day issues where quick turnaround is imperative, the thoroughness of their procedures become a limiting factor. Furthermore, for an effective application of these frameworks, specialised training and working experience is statutory, which may impose a further hindrance. There are other structured problem-solving frameworks, such as Eight Discipline (8D) or A3, that can be used for quick turnaround time. Several applied research studies have been conducted in the area of $8 \mathrm{D}$ framework and its application in the mostly automotive industry. The study presented in the article explores a novel combined approach of $8 \mathrm{D}$ framework with key analytical tools from the Six Sigma methodology and popular industrial techniques in resolving a complex engineering issue with reasonable turnaround time. Next, the study explores the utility of commonly used analytical tools for the assembly processes of the plumbing industry.

This research study was conducted in a UK-based, global plumbing company, renowned for its bathroom products. A soon-to-be-launched mixer shower product was demonstrating a high reject rate for leak failures. The product consisted of 12 key sub-assemblies and components, which went through five assembly stations, and two leak tests at different stages of assembly. At the final leak stage, approx. $12 \%$ of the product was rejected for a high leak rate resulting in a high financial loss due to scrap and re-work. The research study aimed to reduce high leak rejects using a combined approach of the 8D framework in combination with Six Sigma and other analytical tools for root-cause analysis.

\section{LITERATURE REVIEW}

Problem-solving is at the core of human evolution. It is the basis of all new inventions, social and cultural evolution, continuous improvement, collaboration and learning. The evidence for its relevance can be found in prehistoric stone tools available in the archaeological record, those made between 2.5 and 1.5 million years ago in East Africa, which led to the emergence of a new cultural era (Leaky, 1971; Toth, 1985); and Nanorobots created by the University of Pennsylvania that revolutionised the field of medicine and health by performing surgeries and delivering medicine (Carne, 2019).

So, what is problem-solving? It is the act of defining a problem; determining the cause of a problem; identifying, prioritising and selecting alternatives for a solution; and implementing a solution (Riesenberger \& Sousa, 2010). Each step in the problem-solving process employs skills and methods that contribute to the overall effectiveness of influencing change and determine the level of problem complexity that can be addressed. Humans learn how to solve simple problems from a very early age (learning to eat, make coordinated movements and communicate) - and as a person goes through life, problem-solving skills are refined and matured into more sophisticated versions enabling them to solve more difficult issues. Problem-solving is important both to individuals and organisations because it allows exerting control over the environment. Some of the most popular problem-solving frameworks in the manufacturing industry include Six Sigma, TRIZ (Teoriya Resheniya Izobreatatelskikh Zadatch/Theory of Inventive Problem Solving) and TQM (Total Quality Management).

Six Sigma is a systematic set of guidelines that aims to significantly improve the quality of a manufacturing process and reduce costs by minimising the process variation and reducing defects. It utilises statistical tools that can either be applied to facilitate a new product development or strategic process improvement (Breyfogle et al., 2001). In the last decade or so, there has been a rapid uptake of the Six Sigma technique as a process change, management and improvement strategy by global industries. This helped them beat market competition and maximise yearly savings (Su \& Chou, 2008; Yang \& Hsieh, 2009). Besides, in the last decade or so, there has been a massive uptake and implementation of the Six Sigma technique as a process change, management and improvement strategy by global industries, which include the manufacturing process (Al-Aomar, 2006; Gangidi, 2019; Valles et al., 
2009), financial organisations (Brewer \& Eighme, 2005), engineering firms (Bunce et al., 2008), hospitals and intervention clinics (Craven et al., 2006; Olszewska, 2017), banking, hospitality, pharmaceutical companies (Cupryk et al., 2007), chemical industries (Doble, 2005), educational institutions (Bandyopadhyay \& Lichtman, 2007), the software industry (Arul \& Kohli, 2004), call centres (Schmidt \& Aschkenase, 2004), utility service providers (Agarwal \& Bajaj, 2008), the automobile sector (Gerhorst et al., 2006), information technology (Edgeman et al., 2005), human resources departments (Wyper \& Harrison, 2000), military administration units (Chappell \& Peck, 2006) and even government departments (Furterer \& Elshennawy, 2005).

Another popular problem-solving tool TRIZ is considered to be an avant-garde, knowledge-based problem-solving technique (Savranksy, 2000). TRIZ has been argued to serve the dual purpose of new product or systems development as well as provide a set of guidelines for an enhanced understanding of the evolution of technologies and systems (Fey \& Rivin, 2005). It has also been referred to as a toolkit for one of the most rigorous, scientifically organised and sweeping understanding of all aspects of creative problem solving, which gets TRIZ an edge over other innovative problem-solving methods (Gadd, 2011; Livotov, 2008). For instance, other known tools of brainstorming, mind mapping, morphological analysis etc. hold the potential to reveal the root cause of a problem but fail to lead to an effective solution. TRIZ offers innovative solutions when all the possible alternatives have been exhausted and the new exposition can be accepted with confidence (Gadd, 2011). Since its inception in Russia, with mere two institutes for TRZ training (Souchkov, 2008), it has now spread to over 35 countries and is a part of course curriculum across numerous reputed universities as well as part of strategic policies in global companies, such as Ford Motors, Procter \& Gamble, and Mitsubishi (Rantanen \& Domb, 2008).

Yet another influential quality movement that revolutionised problem-solving across industries was Total Quality Management (TQM). TQM was conceptualised and invented in Japan (Cole, 1998; Esaki, 2016; Juran, 1995) as a means of overcoming the loopholes in contemporary investigative techniques. TQM is considered to be an organised strategy emphasising the evidence-based systematic procedure, including the top-down management hierarchy, staff engagement, and inclusion of customer requirements while decision making (Tobin, 1990). The flip side of the coin in this context is that the scope of TQM is too broad and a variety of definitions are possible, which increases the probability of making ineffective permutations of its possibilities, lowering the consistency and reliability of its use just as has been reported in the manufacturing industry (e.g., Andersson et al., 2006; Boaden, 1997; Brown et al., 1994; Eskildson, 1994; Cao et al., 2000; Nwabueze, 2001; Talapatra, Uddin \& Rahman, 2018; Sebestova, 2016). Evidence from independent publications indicated that two-thirds of TQM implementation efforts failed to produce any significant improvements in product quality or the financial, competitive situation of a company (Jimoh et al., 2018). The biggest challenge in applying these technical, rigid problemsolving frameworks is the required knowledge and expertise to use them effectively and efficiently across a range of scenarios, in particular for TRIZ (WedellWedellsborg, 2017; Ilevbare, Probert, \& Phaal, 2013). A comparative summary of the three problem-solving tools discussed in the above section is shown in Table 1.

For the current research scenario, the concerned product was facing a complex issue of high leak rate with a high variation in the assembly process; thus, Six Sigma was deemed to be most appropriate in resolving it. However, as the product was close to the launch date, a quick turnaround strategy demanded a less rigorous methodology than Six Sigma. Therefore, the 8D framework was explored as an additional problem-solving tool. As a cogent methodology, $8 \mathrm{D}$ is designed for the identification of a problem, tracing its root cause, creating a containment fix and further implementing a long-term solution to prevent the recurrence of the problem. Its characteristics make it an excellent choice as a first step in improving the quality and reliability of a defective product that may be causing customer dissatisfaction. Its effectiveness is evident from its use during the World War II by the US government, wherein it was referred to as Military Standard 1520, which means a corrective action and disposition system for nonconforming material (Berk, 2000). The origins of the 8D methodology can be traced back to 1987 when the Ford Company first documented its use in a manual titled "Team Oriented Problem Solving (TOPS)", by the request of the senior management team who were confronting a series of recurring problems for the Power Train organisation of the automaker (Behrens, Wilde \& Hoffmann, 2007). It was found to be so effective, easy to use and reliable that $8 \mathrm{D}$ was officially nominated as the primary method for documenting problem-solving efforts at the Ford Motors and it is still used today. Following Ford, many other manufacturing companies adopted this technique in their toolkit. Some of the case studies are presented in Table 2. 
Tab. 1. Comparative summary of structured problem-solving tools

\begin{tabular}{|l|l|l|l|l|l|}
\hline \multicolumn{1}{|c|}{ CONCEPT } & \multicolumn{1}{|c|}{ ORIGIN } & \multicolumn{1}{|c|}{ AIM } & \multicolumn{1}{c|}{ Focus } & \multicolumn{1}{c|}{$\begin{array}{c}\text { METHODOLOGY } \\
\text { AND TOOLS }\end{array}$} & \multicolumn{1}{c|}{ CRITICISMS } \\
\hline Six Sigma & $\begin{array}{l}\text { Motorola Inc. } \\
\text { (1987) }\end{array}$ & $\begin{array}{l}\text { Improve process } \\
\text { capability }\end{array}$ & $\begin{array}{l}\text { Reduce process } \\
\text { variation by } \\
\text { controlling inputs }\end{array}$ & $\begin{array}{l}\text { Methodology: } \\
\text { DMAIC } \\
\text { Tools: Statistical } \\
\text { techniques }\end{array}$ & $\begin{array}{l}\text { Skilled workers required to } \\
\text { implement, resource- } \\
\text { demanding and long-term }\end{array}$ \\
\hline TRIZ & $\begin{array}{l}\text { Russia } \\
\text { (the 1940s) }\end{array}$ & $\begin{array}{l}\text { To develop inventive } \\
\text { solutions to complex } \\
\text { problems }\end{array}$ & $\begin{array}{l}\text { To understand } \\
\text { contradictions and } \\
\text { resolve them }\end{array}$ & $\begin{array}{l}\text { Methodology: } \\
\text { Tools: } \\
\text { Contradiction } \\
\text { Matrix, ARIX }\end{array}$ & $\begin{array}{l}\text { Difficult to acquire, training, } \\
\text { resource-demanding }\end{array}$ \\
\hline $\begin{array}{l}\text { Total Quality } \\
\text { Management } \\
\text { (TQM) }\end{array}$ & $\begin{array}{l}\text { Japan } \\
\text { (the 1990s) }\end{array}$ & $\begin{array}{l}\text { Improve the quality } \\
\text { and consistency of } \\
\text { processes }\end{array}$ & $\begin{array}{l}\text { Customer } \\
\text { satisfaction }\end{array}$ & $\begin{array}{l}\text { Methodology: } \\
\text { Plan Do Study } \\
\text { Act } \\
\text { Tools: Statistical } \\
\text { techniques }\end{array}$ & $\begin{array}{l}\text { Vague and inconsistent } \\
\text { conceptualisation, excessive } \\
\text { resource consumption, } \\
\text { unsatisfactory results }\end{array}$ \\
\hline
\end{tabular}

Tab. 2. Case summary for the application of the 8D methodology

\begin{tabular}{|l|l|l|}
\hline \multicolumn{1}{|c|}{ AUTHORS } & \multicolumn{1}{|c|}{$\begin{array}{c}\text { NAME OF AN } \\
\text { ORGANISATION }\end{array}$} & \multicolumn{1}{c|}{ BENEFITS OF IMPLEMENTING THE 8D METHODOLOGY } \\
\hline $\begin{array}{l}\text { Behrens, B. -A., Wilde, I. } \\
\text { and Hoffmann, M., 2007; } \\
\text { Rambaud 2006 }\end{array}$ & Ford \& Suppliers & $\begin{array}{l}\text { The 8D methodology started with the Powertrain Organisation of the Ford } \\
\text { Group. With benefits seen from the team-oriented problem solving (TOPS), } \\
\text { it was rolled out business-wide. Soon entire Ford supply chain, including } \\
\text { suppliers, were using the 8D framework }\end{array}$ \\
\hline $\begin{array}{l}\text { Whitfield, R. C. and Kwok, } \\
\text { K. -M., 1996 }\end{array}$ & $\begin{array}{l}\text { Hongkong based } \\
\text { Electronics company }\end{array}$ & $\begin{array}{l}\text { Improving the quality of the Integrated assembly line using Ford's 8D } \\
\text { methodology. Highlights the benefits of highly focused approach with } \\
\text { simple analytical tools of 8D in achieving considerable benefits in a short } \\
\text { time }\end{array}$ \\
\hline $\begin{array}{l}\text { Saidin, W.A.N.W., Ibrahim, } \\
\begin{array}{l}\text { A.M., Azir, M Ngah, H., } \\
\text { Noor N. M. and M.H } \\
\text { Norhidayah., 2014 }\end{array}\end{array}$ & $\begin{array}{l}\text { Automotive Company } \\
\text { (Trim Line) }\end{array}$ & $\begin{array}{l}\text { resulting in financial gains. 8D offers an essential solution from identifying } \\
\text { the root cause until the implementation of preventive action. Quick } \\
\text { turnaround time and easy to implement the methodology }\end{array}$ \\
\hline
\end{tabular}

\section{RESEARCH METHODS}

The overall aim of the research study was to reduce the number of high leak rejects during the manufacturing and assembly process of a mixer shower. As it was a complex engineering problem with a high variation in the manufacturing/assembly process, the Six Sigma methodology was deemed most appropriate. However, as immediate protection to the customers and quick resolution of the problem was required, the $8 \mathrm{D}$ framework combined with key analytical tools from the Six Sigma DMAIC methodology was deemed most appropriate in resolving the issue with a quick turnaround. Step-by-step elucidation of the intricacies in terms of appropriate conditions for implementing it and the procedural details are listed below, in nine stages (Rambaud, 2006):

- D0: Plan to solve the problem and determine its prerequisites. $8 \mathrm{D}$ is a fact-based problem-solving process involving specialised skills and a culture that favours continuous improvement (Duffy, 2013). Additional education and training were provided to identified team members.
- D1: Utilise available resources. A cross-functional team of people who already possess some degree of product/process knowledge were selected.

- D2: Define and describe the problem. The problem was defined in quantifiable terms of 5W2Hs: who, what, where, when, why, how, and how many for the issue of concern.

- D3: Develop an interim containment plan; implement and verify interim actions. At this stage, risks to various customers were identified, and appropriate containment actions were implemented, verified and refined to protect the customers.

- D4: Determine, identify, and verify root causes and escape points. Brainstorm and explore all the possible causes that could explain why that problem might have occurred. Also, detect the reason for the failure to identify the early occurrence of the problem. It is important that any derived hypotheses are scientifically justified and adequately documented. An effective tool for this purpose is the Five Whys and cause-and-effect diagrams to map causes against the effect or the identified problem. Further, key tools of Measure, 
Analyse and Improve the phase from the DMAIC methodology of Six Sigma were utilised in this research study to enhance the validity and sustainability of the implemented solutions. Another popular analytical technique of component search analysis was also used for the root-cause analysis.

- D5: Choose and verify permanent corrections (PCs) for the problem/nonconformity. The proposed solution was evaluated quantitatively through pilot programmes ensuring the problem was resolved for the target customer.

- D6: Implement and validate corrective actions. The best corrective actions (CA) were developed and implemented during this stage.

- D7: Take preventive measures. Transfer lessons learnt to modify the management systems, operation systems, practices, and procedures to prevent recurrence of such problems.

- D8: Congratulate your team. Recognised the team which will act as a motivator and facilitate sustainable changes across the organisation.

\section{RESEARCH RESULTS}

Structured problem solving was designed by using a combination of 8-Discipline and the Six Sigma methodology together with key industry-standard analytical tests. The identified problem was diagnosed as a high number of leak rejects from a mixer shower assembly line, which could result in significant financial losses and tarnish the company's reputation, if the product would hit the market with this defect. The entire process of structured problem-solving was split into nine key stages as delineated in the methodology section above. Specifics of each stage for the current scenario are discussed below:

D0: Prepare and Plan for the $8 \mathrm{D}$. The initial evaluation of the problem suggested the appropriateness of using the 8D framework together with the Six Sigma methodology. During this stage, preparations were made to initiate the problem-solving process, and adequate training was delivered to the concerned personnel.

D1: Form the team. A cross-functional team was formed from representatives of design, manufacturing, operations, supply chain (purchasing \& supplier quality assurance) and quality departments. It was further ensured that they were competent in the $8 \mathrm{D}$ framework and the Six Sigma methodology.

D2: Describe the Problem.
The first step was to collect initial data related to the problem with the help of "Is/Is Not" analysis. Historical data demonstrate that the mean daily failure rate is 0.1184 or $11.84 \%$ with no clear trend (Fig. 1). Once the necessary information was available, the following problem statement was generated: " $11.84 \%$ of the finished products failed the Shutoff Leak Test for Product X Line, which resulted in re-work/scrap."

A scoping diagram was created for the initial project scoping, which helped to focus problem-solving efforts towards 11 key areas (Fig. 2). Items found to be outside the scope in this step were still considered to be relevant for further investigation during the 2nd iteration of the problem-solving process. However, the process terminates at this step if the root cause gets identified.

D3: Containment. During this stage, the main focus was to protect an external and internal customer. The review of failure using the FMEA strategy revealed that chances of a faulty product escaping the assembly line were negligible as it would have been detected by the end of the line quality checks. The initial containment was to reject and quarantine a faulty product for an engineering investigation. At this stage, an external customer was fully protected; however, scrap parts from the rejects incurred cost and throughput risks for the internal customer (Production \& Engineering). The initial RCA work discussed in the next section suggested that the re-working of the product could be the next stage of containment. As RCA work further progressed, it helped to refine the re-work process by creating a clear and simple re-work procedure, which fixed the majority of the rejected products. The re-work was to replace housing, send it for a leak test, and if a part gets rejected again, manually file the split lines and send for a leak test again.

D4. Root-Cause Analysis (RCA). During this phase, some principles from the Six Sigma methodology, especially the techniques used in the "Measure, Analyse and Improve" phase of Six Sigma were used. Further common tools and techniques used in the industry were also employed. As a first step, the measurement equipment used for measuring the Key Process Output Variable (Leak Rate) was validated. Annual Gage $R \& R$ was successfully completed with daily checks. The use of the artefact standard was also found to be within control limits and high Cgk of 1.51, as shown in Fig. 3.

Drawing on insights gained from the initial investigation and historical data, a four-staged "Component Search" analysis was conducted on the sub-assembly to 


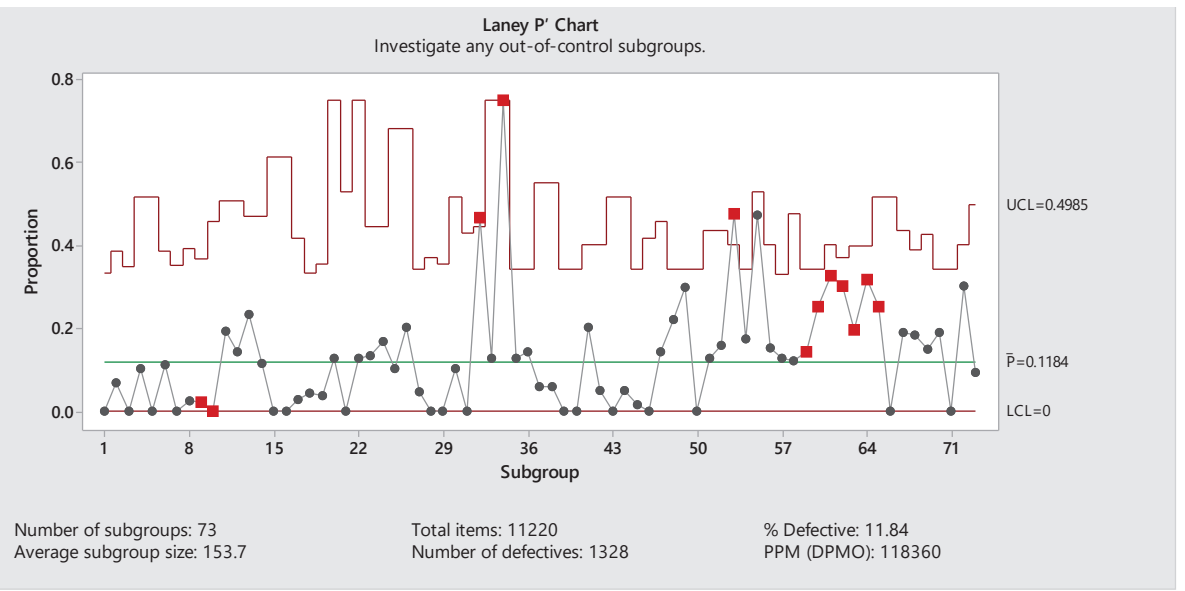

Fig. 1. Proportions control chart showing the daily reject trend

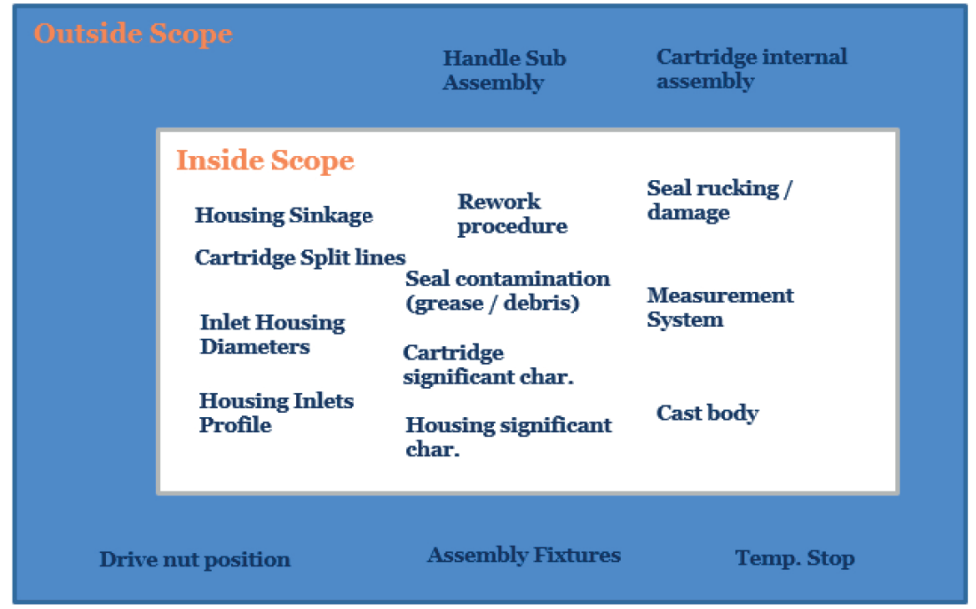

Fig. 2. Scoping diagram

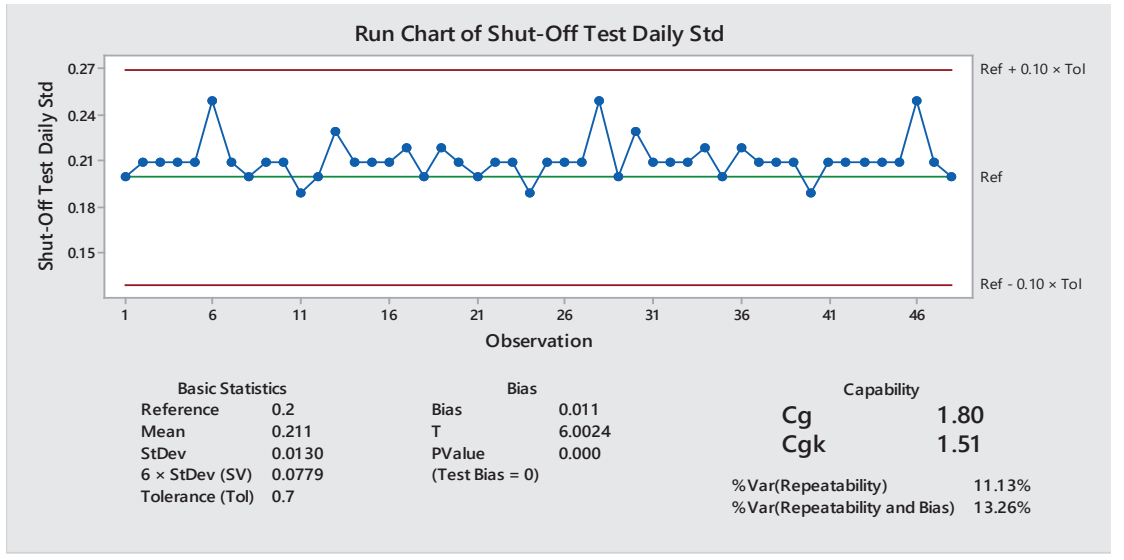

Fig. 3. Capability report for leak Rate Measuring Equipment

identify, which component was faulty. A step-by-step procedure is presented below:

Stage 1. One best and one worst product were sampled. They were built and rebuilt three times and measured for the Measurable Customer Response, which was the leak rate in this case. From this data, the upper and lower decision limits were calculated using statistics, as shown in Table 3.
Stage 2. Key components were swapped one at a time between the best and the worst samples. After every component swap, samples were measured again for the leak rate. Leak rate results for housing and cartridge swap fell outside the decision limits, indicating that they were important components for the leak rate.

Stage 3. Both important components (housing and cartridge) were then swapped together between the 
Tab. 3. Component search analysis results from Stages 1 and 2

\begin{tabular}{|c|c|c|c|c|c|c|c|}
\hline TEST DESCRIPTION & BEST & WORST & $\begin{array}{l}\text { HIGH } \\
\text { LOWER } \\
\text { DECISION } \\
\text { LIMIT }\end{array}$ & $\begin{array}{c}\text { HIGH } \\
\text { UPPER } \\
\text { DECISION } \\
\text { LIMIT }\end{array}$ & $\begin{array}{c}\text { LOW } \\
\text { LOWER } \\
\text { DECISION } \\
\text { LIMIT }\end{array}$ & $\begin{array}{l}\text { LOW UPPER } \\
\text { DECISION } \\
\text { LIMIT }\end{array}$ & ANALYSIS \\
\hline Initial & 0.21 & 1.88 & 0.1335 & 0.2865 & 1.8035 & 1.9565 & \\
\hline First Rebuild & 0.25 & 1.85 & 0.1335 & 0.2865 & 1.8035 & 1.9565 & \\
\hline Second Rebuild & 0.2 & 1.9 & 0.1335 & 0.2865 & 1.8035 & 1.9565 & \\
\hline \multicolumn{8}{|l|}{ Stage 2: Replace } \\
\hline Cast Body & 0.2 & 1.85 & 0.1335 & 0.2865 & 1.8035 & 1.9565 & Not important \\
\hline Housing & 0.6 & 1.72 & 0.1335 & 0.2865 & 1.8035 & 1.9565 & $\begin{array}{l}\text { Important, so is } \\
\text { something else }\end{array}$ \\
\hline Cartridge & 1.65 & 0.4 & 0.1335 & 0.2865 & 1.8035 & 1.9565 & $\begin{array}{l}\text { Important, so is } \\
\text { something else }\end{array}$ \\
\hline Brass Nut & 0.19 & 1.86 & 0.1335 & 0.2865 & 1.8035 & 1.9565 & Not important \\
\hline Cartridge Top Seal & 0.2 & 1.89 & 0.1335 & 0.2865 & 1.8035 & 1.9565 & Not important \\
\hline $\begin{array}{l}\text { Cartridge Bottom } \\
\text { Seal }\end{array}$ & 0.22 & 1.9 & 0.1335 & 0.2865 & 1.8035 & 1.9565 & Not important \\
\hline $\begin{array}{l}\text { Housing Face } \\
\text { Seals }\end{array}$ & 0.25 & 1.88 & 0.1335 & 0.2865 & 1.8035 & 1.9565 & Not important \\
\hline
\end{tabular}

Tab. 4. Component Search Analysis results from Stage 3

\begin{tabular}{|l|l|l|r|r|r|r|r|}
\hline \multicolumn{1}{|c|}{ TEST DESCRIPTION } & BEST & WORST & $\begin{array}{c}\text { HIGH } \\
\text { LOWER } \\
\text { DECISION } \\
\text { LIMIT }\end{array}$ & $\begin{array}{c}\text { HIGH } \\
\text { UPPER } \\
\text { DECISION } \\
\text { LIMIT }\end{array}$ & $\begin{array}{c}\text { LOW } \\
\text { LOWER } \\
\text { DECISION } \\
\text { LIMIT }\end{array}$ & $\begin{array}{c}\text { LOW } \\
\text { UPPER } \\
\text { DECISION } \\
\text { LIMIT }\end{array}$ & ANALYSIS \\
\hline Stage 3: Replace & 1.88 & 0.22 & 0.1335 & 0.2865 & 1.8035 & 1.9565 & 2 important factors explain the variation \\
\hline
\end{tabular}

best and the worst samples and measured for the leak rate. Based on the results, the previously best sample was then the worst sample and vice versa (Table 4) suggesting that these two components (housing and cartridge) were responsible for the most variation found in the leak rate.

Stage 4. The main effect and interaction plots in Minitab software were generated using data from the previous stages (Fig. 4). These two components were significant, but the interaction between them was not clear.
The next step was to identify the specific parameter within these two components that might have been critical for failures. Paired comparison using Tukey test was performed. Key parameters that define or could affect failures were identified, twelve in total. Then, eight good and eight bad products were selected and measured for these twelve key parameters. Results from the paired comparison using Tukey test are shown in Tables 5 and 6.

Results from the paired comparison test found two parameters to be statistically significant for high

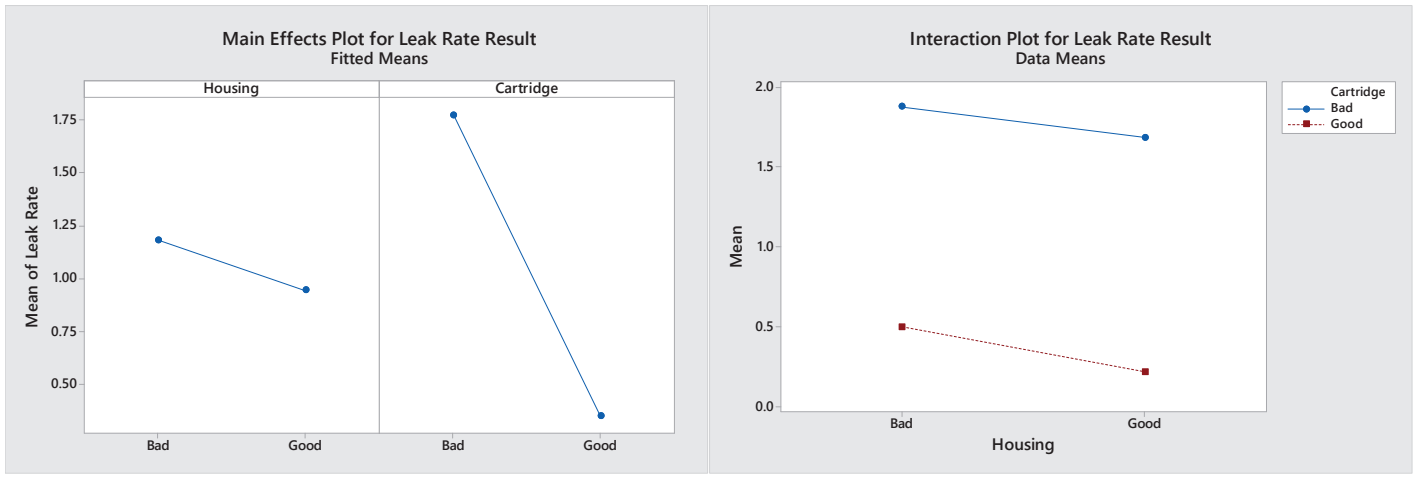

Fig. 4. Main effect and interaction plots for housing and cartridge 
Tab. 5. Paired comparison (sorted results) for key parameters of the housing

\begin{tabular}{|c|c|c|c|c|c|c|c|c|c|c|c|}
\hline \multicolumn{2}{|c|}{$\begin{array}{l}\text { HOUSING BOTTOM } \\
\text { DIAMETER (MM) }\end{array}$} & \multicolumn{2}{|c|}{$\begin{array}{l}\text { HOUSING BOTTOM } \\
\text { RouNDNESS (MM) }\end{array}$} & \multicolumn{2}{|c|}{$\begin{array}{l}\text { HOUSING BOTTOM } \\
\text { CONCENTRICITY (MM) }\end{array}$} & \multicolumn{2}{|c|}{$\begin{array}{c}\text { HOUSING TOP } \\
\text { DIAMETER (MM) }\end{array}$} & \multicolumn{2}{|c|}{$\begin{array}{c}\text { Housing TOP } \\
\text { RoUNDNESS (MM) }\end{array}$} & \multicolumn{2}{|c|}{$\begin{array}{c}\text { HOUSING TOP } \\
\text { CONCENTRICITY (MM) }\end{array}$} \\
\hline Bad & 29.665 & Good & 0.077 & Bad & 0.049 & Good & 32.432 & Good & 0.142 & Good & 0.025 \\
\hline Good & 29.667 & Good & 0.078 & Good & 0.13 & Good & 32.435 & Good & 0.142 & Good & 0.026 \\
\hline Good & 29.667 & Bad & 0.079 & Bad & 0.136 & Bad & 32.44 & Bad & 0.145 & Bad & 0.027 \\
\hline Bad & 29.668 & Bad & 0.082 & Good & 0.161 & Bad & 32.44 & Bad & 0.146 & Bad & 0.027 \\
\hline Good & 29.669 & Good & 0.084 & Bad & 0.162 & Good & 32.44 & Bad & 0.148 & Bad & 0.027 \\
\hline Good & 29.67 & Good & 0.088 & Bad & 0.163 & Good & 32.442 & Good & 0.142 & Good & 0.028 \\
\hline Good & 29.67 & Good & 0.088 & Bad & 0.163 & Bad & 32.442 & Bad & 0.145 & Good & 0.028 \\
\hline Bad & 29.67 & Bad & 0.089 & Good & 0.163 & Bad & 32.442 & Good & 0.145 & Bad & 0.029 \\
\hline Bad & 29.67 & Bad & 0.092 & Bad & 0.164 & Bad & 32.442 & Good & 0.153 & Good & 0.029 \\
\hline Good & 29.671 & Good & 0.093 & Bad & 0.164 & Good & 32.442 & Good & 0.154 & Good & 0.03 \\
\hline Bad & 29.671 & Bad & 0.093 & Good & 0.167 & Good & 32.443 & Good & 0.181 & Bad & 0.03 \\
\hline Bad & 29.671 & Bad & 0.095 & Good & 0.168 & Good & 32.443 & Good & 0.187 & Good & 0.031 \\
\hline Bad & 29.671 & Good & 0.098 & Good & 0.172 & Bad & 32.444 & Bad & 0.19 & Bad & 0.032 \\
\hline Bad & 29.672 & Good & 0.104 & Bad & 0.173 & Bad & 32.445 & Bad & 0.198 & Bad & 0.033 \\
\hline Good & 29.674 & $\mathrm{Bad}$ & 0.111 & Good & 0.175 & Bad & 32.453 & Bad & 0.2 & Good & 0.049 \\
\hline Good & 29.674 & Bad & 0.124 & Good & 0.176 & Good & 32.454 & Bad & 0.201 & Bad & 0.065 \\
\hline Top EC & 1 & & 2 & & 1 & & 2 & & 2 & & 2 \\
\hline Bottom EC & 2 & & 2 & & 2 & & 0 & & 4 & & 1 \\
\hline $\begin{array}{l}\text { Total EC } \\
\%\end{array}$ & 3 & & 4 & & 3 & & 2 & & 6 & & 3 \\
\hline Confidence & None & & None & & None & & None & & $90 \%$ & & None \\
\hline
\end{tabular}

Tab. 6. Paired comparison (sorted results) for key parameters of the cartridge

\begin{tabular}{|c|c|c|c|c|c|c|c|c|c|c|c|}
\hline \multicolumn{2}{|c|}{$\begin{array}{l}\text { CARTRIDGE BOTTOM } \\
\text { DIAMETER (MM) }\end{array}$} & \multicolumn{2}{|c|}{$\begin{array}{c}\text { CARTRIDGE } \\
\text { BOtTOM } \\
\text { RouNDNESS (MM) }\end{array}$} & \multicolumn{2}{|c|}{$\begin{array}{l}\text { CARTRIDGE TOP } \\
\text { DIAMETER (MM) }\end{array}$} & \multicolumn{2}{|c|}{$\begin{array}{c}\text { CARTRIDGE TOP } \\
\text { ROUNDNESS (MM) }\end{array}$} & \multicolumn{2}{|c|}{$\begin{array}{l}\text { CARTRIDGE TOP SPLIT- } \\
\text { LINES (MM) }\end{array}$} & \multicolumn{2}{|c|}{$\begin{array}{l}\text { CARTRIDGE BOTTOM } \\
\text { SPLIT-LINES (MM) }\end{array}$} \\
\hline Good & 26.342 & Bad & 0.053 & Good & 28.309 & Good & 0.097 & Good & 0 & Good & 0.01 \\
\hline Good & 26.349 & Good & 0.057 & Good & 28.31 & Good & 0.102 & Good & 0 & Good & 0.01 \\
\hline Bad & 26.351 & Bad & 0.059 & Good & 28.311 & Good & 0.106 & Good & 0.01 & Good & 0.01 \\
\hline Bad & 26.357 & Good & 0.06 & Bad & 28.315 & Bad & 0.108 & Bad & 0.015 & $\mathrm{Bad}$ & 0.015 \\
\hline $\mathrm{Bad}$ & 26.358 & Bad & 0.061 & Good & 28.315 & Bad & 0.109 & Bad & 0.018 & $\mathrm{Bad}$ & 0.018 \\
\hline Good & 26.364 & Good & 0.063 & Good & 28.315 & Good & 0.109 & Good & 0.019 & Good & 0.018 \\
\hline Bad & 26.366 & Good & 0.065 & Bad & 28.316 & Bad & 0.109 & Bad & 0.021 & $\mathrm{Bad}$ & 0.018 \\
\hline Good & 26.369 & Good & 0.073 & Bad & 28.317 & Good & 0.111 & Good & 0.021 & Good & 0.019 \\
\hline Good & 26.371 & Good & 0.073 & Bad & 28.319 & Good & 0.112 & Good & 0.022 & Bad & 0.019 \\
\hline Bad & 26.372 & Bad & 0.084 & Bad & 28.32 & Good & 0.12 & Good & 0.025 & $\mathrm{Bad}$ & 0.02 \\
\hline Bad & 26.373 & Bad & 0.086 & Bad & 28.32 & Bad & 0.132 & Good & 0.03 & Good & 0.02 \\
\hline Good & 26.375 & Bad & 0.087 & Bad & 28.32 & Bad & 0.134 & Bad & 0.035 & Bad & 0.021 \\
\hline Good & 26.378 & Bad & 0.091 & Good & 28.321 & Bad & 0.137 & Bad & 0.038 & Bad & 0.025 \\
\hline Bad & 26.38 & Good & 0.091 & Bad & 28.322 & Bad & 0.139 & Bad & 0.041 & Good & 0.028 \\
\hline $\mathrm{Bad}$ & 26.383 & Bad & 0.095 & Good & 28.337 & Good & 0.139 & Bad & 0.045 & Good & 0.028 \\
\hline Good & 26.39 & Good & 0.115 & Good & 28.344 & Bad & 0.144 & Bad & 0.051 & Bad & 0.03 \\
\hline Top EC & 2 & & 1 & & 3 & & 3 & & 3 & & 3 \\
\hline Bottom EC & 0 & & 1 & & 0 & & 1 & & 5 & & 1 \\
\hline $\begin{array}{l}\text { Total EC } \\
\%\end{array}$ & 2 & & 2 & & 3 & & 4 & & 8 & & 4 \\
\hline Confidence & None & & None & & None & & None & & $>95 \%$ & & None \\
\hline
\end{tabular}


leak rates and failures, namely, roundness at the top half of the housing and also the top cartridge split lines. Closer scrutiny of this data revealed another layer of difficulty: that the top radial seal was failing to perform adequately that was resulting in leaks. The top split line was another significant parameter, but all the data was within specification and wasn't a problem on other similar products. To further investigate this issue, profiling of both housing and cartridge was conducted, the results of which are shown in Fig. 5 and 6.

Two spikes seen on the cartridge profile are split lines. The housing profile shows that it is oval in shape and provides less seal compression around the split lines region and more compression at $+/$ - 90 degrees of split lines. This analysis revealed yet another cause for high leak rates, which were higher split lines and oval housing.

D5. Choose and Validate Permanent Correction. As discussed in the previous section, two key param-

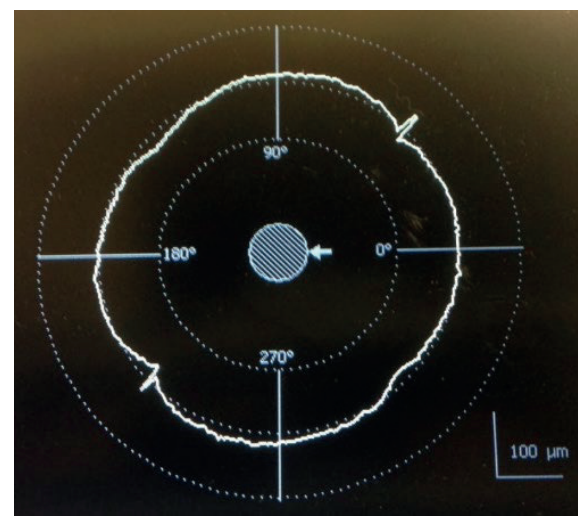

Fig. 5. Cartridge top-sealing face profile eters were found responsible for a high leak rate or rejects. Firstly, it was top cartridge split lines that needed to be less than $0.05 \mathrm{~mm}$ to reduce leak rejects, but it was almost impossible to achieve this through the injection moulding process. The other option was to increase the seal compression around the split line region by improving the roundness of the housing. Before introducing the change, to ascertain that housing roundness was the most significant factor, two quick tests were conducted using the existing resources. Before starting the test, ten worst samples were created and measured for the leak rate to establish the reference condition. The first experiment was to replace the oval housing of these ten parts with a machined metal housing having good roundness. The second test was to rotate the existing oval housings by 90 degrees to give an increased seal compression around split lines. Leak rate results from all three conditions are shown in Fig. 7.

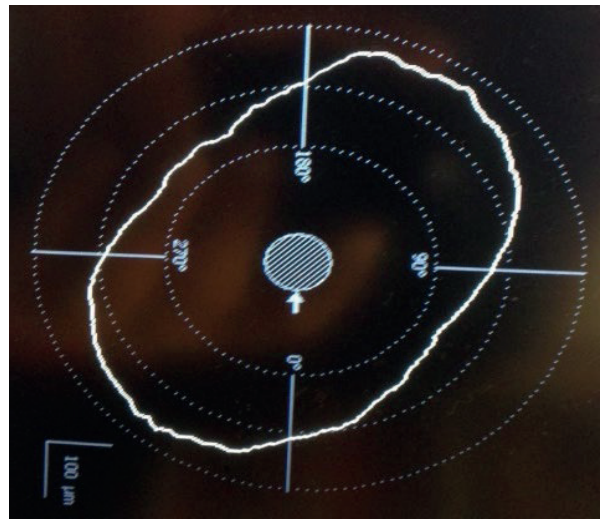

Fig. 6. Housing top-sealing face profile

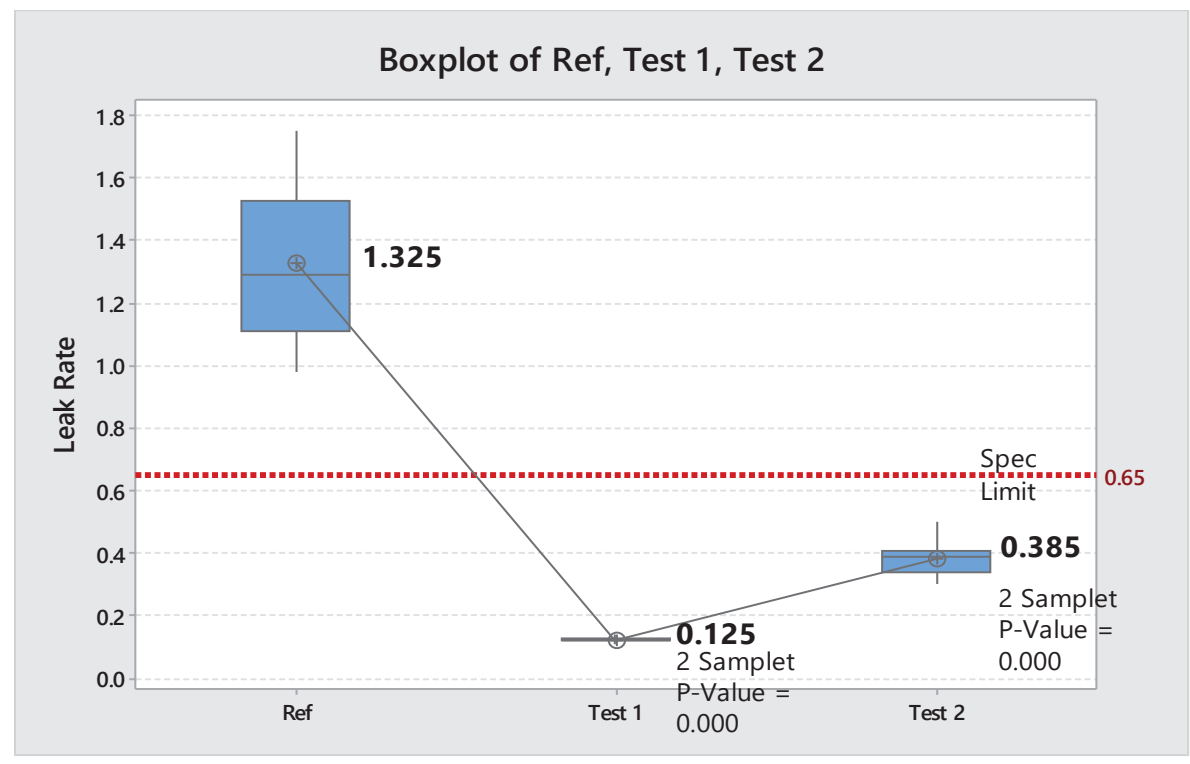

Fig. 7. Comparison among different test conditions 


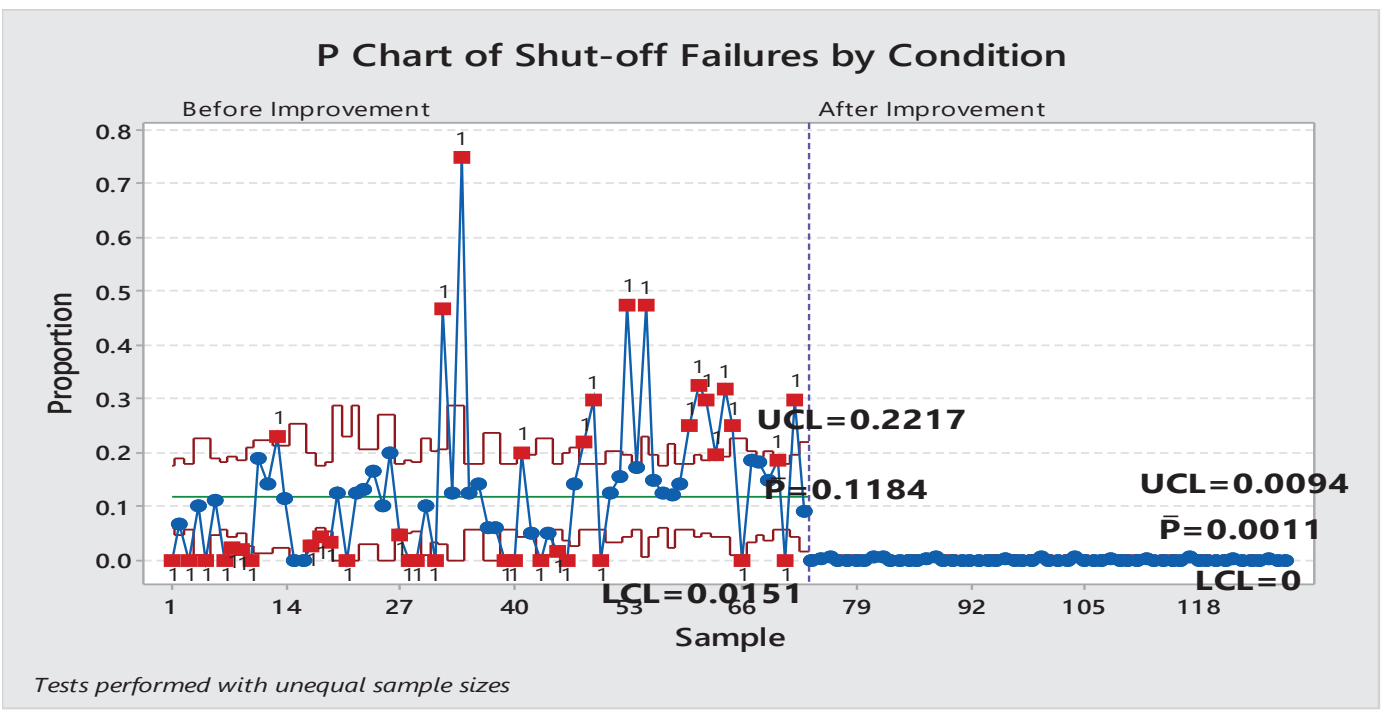

Fig. 8. Impact of PCA through P Chart of shut off failures

Both test conditions were statistically better than the reference. So, by improving the roundness of housing or increased compression around split lines, the leak rate can be reduced, thereby eliminating the failures.

D6. Implement and Validate the Permanent Corrective Action. Permanent corrective action was to improve the housing roundness with injection moulding supplier. From previous data analysis conducted during the RCA phase, an upper specification limit of $0.075 \mathrm{~mm}$ was applied to the housing roundness. A significant reduction in shut-off failures from $11.84 \%$ to $0.11 \%$ was observed after the improved condition, as shown in Fig. 8.

D7. Prevent Recurrence. To prevent recurrence of the failure mode, Design FMEA and Control Plan were updated. Detailed feedback on the lessons learnt and new knowledge acquired regarding the specific issue in the current organisation was also shared with the rest of the new and current product development team.

D8. Closure and Team Celebration. The results of the project and the team's achievement were shared with a wider audience using a company magazine and various departmental monthly meetings.

\section{DISCUSSION OF RESULTS}

The current implementation of the 8-Discipline framework combined with the Six Sigma methodology along with key industry-standard analytical tests proved successful against key project deliverables.
The issue of a high leak-reject rate was clearly defined, thereby effective immediate containment was applied to reduce the impact on key stakeholders. Consistent with evidence of previous research (Mishra, 2018; Wedell-Wedellsborg 2017; Pyzdek, 2003), defining the problem is critical to achieving a permanent resolution of the issue. Defining the problem during the D1 stage largely consisted of ensuring that the team members understood the nature of the problem and what was expected of them, and spending time on developing a clear problem statement helped all team members to work towards a common goal and channel efforts in the right direction, avoiding any ambiguity or confusion.

The research study found that as progress was made through the $8 \mathrm{D}$ process, initial/interim containment that was put in place could be further refined. Initially, to prevent a faulty product reaching a customer, all parts were rejected and quarantined. Gaining insights into the issue through the D4 stage using Six Sigma statistical tools and componentsearch analysis, it was found that re-working the cartridge sub-assembly could reduce the failure rate. So, the second interim containment, which was to change the housing and cartridge one at a time, was created, which helped to reduce the number of rejected products. But it created another problem with the re-work cost that included re-work time and rejected components. As RCA investigation progressed further, the 3rd interim containment was introduced to re-work (file) the split lines on the cartridge. This reduced the re-work time and eliminated the cost of rejected components. As RCA and developing permanent 
corrective action can take some time, it is advisable to refine or further develop interim containment action to reduce the impact of the problem. This was a novel finding.

Previous studies have shown that both $8 \mathrm{D}$ (Riesenberger \& Sousa, 2010; Kaplík et al., 2013) and Six Sigma (Swarnakar, Vinodh \& Antony, 2016; Ghosh \& Rao, 1996) were highly effective in identifying the root cause of the problem and developing a permanent corrective action accordingly. Generally, $8 \mathrm{D}$ is used for less complex problems with quick response time, and Six Sigma - for more complex issues. However, there is a scarcity of studies on the benefits of combing the two approaches together to resolve complex problems with quick turnaround time. During the research study, Six Sigma statistical tools were used during D4, namely, the root-cause analysis part of $8 \mathrm{D}$ was used to resolve a relatively complex problem. The entire process from the problem identification to implementing a permanent corrective action tool only eight weeks with a couple of weeks added to verify the permanent corrective action. Generally, an $8 \mathrm{D}$ project takes three months, and a Six Sigma project takes six months to complete. It was found that this combined approach achieved the best result compared to both separate methodologies and resulted in a resolution of a complex problem within three months.

In line with previous research studies, $8 \mathrm{D}$ (Riesenberger \& Souza, 2010; Laurie, 2006) and Six Sigma (Swarnakar, Vinodh \& Antony, 2016) prevent recurring failures. The cost of recurring failures has a major financial impact on the company as well as results in customer dissatisfaction Based on the current research study results, it can be argued that the current methodology helped to prevent the recurrence of failures as the assembly line has been running for a year now without a recurrence of this failure mode.

It can be argued that the combined methodology used in this research study is relatively easy to use, but some basic training is essential. As suggested by other authors (Wedellsborg, 2016; Rebecca, 2018), some basic understanding of the $8 \mathrm{D}$ framework and the Six Sigma methodology is necessary to effectively solve the problems. For these reasons, team members with no prior hands-on experience of $8 \mathrm{D}$ received half a day training with regular mentoring throughout the project. Further, specific tasks requiring Six Sigma skillsets were conducted under the guidance of a certified Six Sigma Black Belt expert.

\section{LIMITATIONS}

It has only been a year since permanent corrective actions were implemented. It is a reasonable length of time to make conclusions, but more data need to be collected in terms of the number of research studies and the length of time to further enhance confidence.

\section{CONCLUSIONS}

The aim of the study was to reduce a high number of leak defects from the mixer shower assembly line in the bath \& shower industry using a combination of 8-Discipline and the Six Sigma methodology together with key industry-standard analytical tests. It was a novel application as previously, 8D and Six Sigma had been implemented independently across several industries, such as finance, service, manufacturing and non-manufacturing, but never together for the mixer shower production in the bath \& shower industry. A significant reduction in rejects from $11.84 \%$ to $0.11 \%$ was achieved within pre-defined time constraints. Housing and cartridge were identified as the key components having a significant impact on a high leak defect rate. Furthermore, key characteristics of these components - the cartridge split line and the housing roundness - were characterised and tolerances were applied accordingly.

Resolving complex problems under the time constraint is a big challenge for any root-cause analysis team and methodology. $8 \mathrm{D}$ provides a structured problem resolution within a limited time but may fall short when dealing with complex systems and products. On the other hand, the Six Sigma methodology provides a comprehensive framework for a complex problem resolution. However, when quick management of complex problems is required, a combined approach, as shown during the research study, is recommended. The issue of high leak rejects was managed from the perspective of all stakeholders and cost to business was kept to a minimum while the permanent corrective action was found for the problem.

Overall, the combined approach of 8-Discipline and the Six Sigma methodology together with key industry-standard analytical tests, proved successful in resolving a complex issue in the bath and shower industry within time constraints. The current research study was conducted on a new product, but the tech- 
nology was similar to that of previous products in terms of assembly, sealing of components etc. It will, therefore, be useful for future research to try this methodology on a new innovative product in the absence of historical product knowledge.

\section{LITERATURE}

Agarwal, R., \& Bajaj, N. (2008). Managing outsourcing process: applying six-sigma. Business Process Management Journal, 14(6), 829-837. doi: $10.1108 / 14637150810916008$

Al-Aomar, R. (2006). A simulation-based DFSS for a lean service system. International Journal of Product Development, 3(3/4), 349-368. doi: 10.1504/ IJPD.2006.009898

Andersson, R., Eriksson, H., \& Torstensson, H. (2006). Similarities and differences between TQM, six-sigma and lean. The TQM Magazine, 18(3), 282-296. doi: 10.1108/09544780610660004

Arul, K., \& Kohli, H. (2004). Six-sigma for software application of hypothesis tests to software Data. Software Quality Journal, 12(1), 29-42. doi: 10.1023/B:SQ JO.0000013357.75406.91

Bandyopadhyay, J., \& Lichtman, R. (2007). Six-sigma approach to quality and productivity improvement in an institution for higher education in the United States. International Journal of Management, 24(4), 802-808

Behrens, B. A., Wilde, I., \& Hoffmann, M. (2007). Complaint management using the extended $8 \mathrm{D}$-method along the automotive supply chain. Production Engineering, 1(1), 91-95. doi: 10.1007/s11740-007-0028-6

Berk J., \& Berk, S. (2000). Quality management for the technology sector. Boston, United States: Newnes.

Boaden, R. J. (1997). What is total quality management and does it matter? Total Quality Management, 8(4), 153171.

Brewer, P., \& Bagranoff, N. A. (2004). Near zero-defect accounting with six-sigma. Journal of Corporate Accounting \& Finance (Wiley), 15(2), 43-67. doi: 10.1002/jcaf.10235

Breyfogle, F. W., Cupello, J. M., \& Meadows, B. (2001a). Managing Six Sigma: A Practical Guide to Understanding, Assessing, and Implementing the Strategy That Yields Bottom-Line Success. New York, United States: Wiley.

Brown, M. G., Hitchcock, D. E., \& Willard, M. A. (1994). Why TQM fails and what to do about it. Boston, United States: Irwin Professional.

Bunce, M., Wang, L., \& Bidanda, B. (2008). Leveraging six-sigma with industrial engineering tools in crateless retort production. International Journal of Production Research, 46(23), 6701-6719. doi: 10.1080/00207540802230520.

Cao, G., Clarke, S., \& Lehaney, B. (2000). A systematic view of organisational change and TQM. The TQM Magazine, 12(3), 186-193. doi: 10.1108/09544780010320241

Carne, N. (2019). Researchers make a million tiny robots. Cosmos Magazine, 8 March 2019.
Chappell, A., \& Peck, H. (2006). Risk management in military supply chains: is there a role for six-sigma? International Journal of Logistics, 9(3), 253-267. doi: 10.1080/13675560600859276

Cole, R. (1998). Learning from the quality movement. California Management Review, 41, 43-73. doi: $10.2307 / 41165975$

Craven, E., Clark, J., Cramer, M., Corwin, S., \& Cooper, M. (2006). New York-Presbyterian hospital uses sixsigma to build a culture of quality and innovation. Journal of Organizational Excellence, 25(4), 11-19. doi: 10.1002/joe.20108

Cupryk, M., Takahata, D., \& Morusca, D. (2007). Crashing the schedule' in DCS validation pharmaceutical projects with lean Six-sigma and project management techniques: case study and discussion. Journal of Validation Technology, 13(3), 222-233.

De Fruyt, F., Wille, B., \& John, O. (2015). Employability in the 21st Century: Complex (Interactive) Problem Solving and Other Essential Skills. Industrial and Organizational Psychology, 8(2), 276-281. doi: 10.1017/ iop. 2015.33

Doble, M. (2005). Six-sigma and chemical process safety. International Journal of Six-sigma and Competitive Advantage, 1(2), 229-244. doi: 10.1504/IJSSCA.2005.006425

Duffy, G. L. (2013) Modular Kaizen - Continuous and Breakthrough Improvement. ASQ Quality Press.

Edgeman, R., Bigio, D., \& Ferleman, T. (2005). Six-sigma and business excellence: strategic and tactical examination of IT service level management at the office of the chief technology officer of Washington, DC. Quality and Reliability Engineering International, 21(3), 257-273. doi: 10.1002/qre.635

Esaki, K. (2016). Common Management Process Model of new TQM based on the situation analysis. Intelligent Information Management, 8(6), 181-193. doi: 10.4236/iim.2016.86013

Eskildson, L. (1994). Improving the odds of TQM's success. Quality Progress, 27(4), 61-63.

Fey, V., \& Rivin, E. I. (2005). Innovation on Demand: new product development using TRIZ. Cambridge, United Kingdom: Cambridge University Press.

Furterer, S., \& Elshennawy, A. (2005). Implementation of TQM and lean six-sigma tools in local government: a framework and a case study. Total Quality Management and Business Excellence, 16(10), 11791191.

Gadd, K. (2011). TRIZ for Engineers. West Sussex, United Kingdom: John Wiley \& Sons.

Gangidi, P. R. (2019). Application of Six Sigma in Semiconductor Manufacturing: A Case Study in Yield Improvement, Applications of Design for Manufacturing and Assembly. Ancuţa Păcurar, IntechOpen. doi: 10.5772/intechopen.81058. Retrieved from https:// www.intechopen.com/books/applications-of-design-for-manufacturing-and-assembly/applicationof-six-sigma-in-semiconductor-manufacturing-acase-study-in-yield-improvement

Ghosh, S., \& Rao, C. R. (Eds.) (1996). Handbook of Statistics 13: Design and analysis of experiments. NorthHolland. 
Ilevbare, I. M., Probert, D. \& Phaal, R. (2013), A review of TRIZ, and its benefits and challenges in practice. Technovation, 33, 30-37. doi: 10.1016/j.technovation.2012.11.003

Jimoh, R., Oyewobi, L., Isa, R., \& Waziri, I. (2018). Total Quality Management Practices and organisational performance: the mediating role of strategies for continuous improvements. International Journal of Construction Management, 19(2), 162-177. doi: 10.1080/15623599.2017.1411456

Juran, J. (1995b). Summary, trends, and prognosis. In J. M. Juran (Ed.), A History of managing for quality: The evolution, trends and future directions of managing for quality (pp. 603-657). Milwaukee, United States: ASQC Quality Press.

Kaplík, P., Prístavka, M., Bujna, M., \& Viderňan, J. (2013). Use of 8D Method to Solve Problems. Advanced Materials Research Online, 801, 95-101. doi: 10.4028/ www.scientific.net/AMR.801.95

Laurie, R. (2006). 8D Structured Problem Solving: A Guide to Creating High Quality 8D Reports.

Leakey, M. (1971). Olduvai Gorge. Volume 3. Excavations in Beds I and II,1960-1963. Cambridge, United Kingdom: Cambridge University Press.

Livotov, P. (2008). TRIZ and Innovation Management. Retrieved from http://www. triz.it/triz_papers/2008\%20 TRIZ\%20and\%20Innovation\%20Management.pdfS

Mishra, M. N. (2018). Identify critical success factors to implement integrated green and Lean Six Sigma. International Journal of Lean Six Sigma. doi: 10.1108/IJLSS-07-2017-0076

Nwabueze, U. (2001). An industry betrayed: the case of total quality management in manufacturing. The TQM Magazine, 13(6), 400-408. doi: 10.1108/ EUM0000000006177

Olszewska, A. M. (2017). Research issues undertaken within quality management - the overview of selected literature. Engineering Management in Production and Services, 9(1), 74-83. doi: 10.1515/emj-2017-0008

Pyzdek, T. (2019). The six-sigma handbook: A complete guide for black belts, green belts and managers at all levels, $5^{\text {th }}$ ed. New York, United States: McGraw-Hill.

Rambaud, L. (2006). 8D Structured Problem Solving: A Guide to Creating High Quality 8D Reports. Breckenridge, United States: Phred Solutions.

Rantanen, K., \& Domb, E. (2008). Simplified TRIZ - new problem solving applications for engineers and manufacturing professionals. New York, United States: Auerbach Publications.

Rebecca, S. (2018). Introduction to 8D Problem Solving: Including Practical Applications and Examples. The Quality Management Journal, 25(4), 201. doi: 10.1080/10686967.2018.1515526

Riesenberger, C. A., \& Sousa, S. D. (2010). The 8D Methodology: An Effective Way to Reduce Recurrence of Customer Complaints? Proceedings of the World Congress on Engineering 2010 Vol III, WCE 2010, 30 June - 2 July 2010, London, United Kingdom.

Saidin, W. A. N. W., Ibrahim, M. A., Azir, M. Z., Ngah, H., Noor, M. N., \& Norhidayah, M. H. (2014). 8D Methodology: An Effective Approach for Problem Solving in Automotive Assembly Line. Australian Journal of Basic and Applied Science, 8(22), 31-34.

Savranksy, S. D. (2000). Engineering of creativity - introduction to TRIZ methodology of inventive problem solving. Boca Raton, United States: CRC Press.

Schmidt, M., \& Aschkenase, S. (2004). The building blocks of service. Supply Chain Management Review, 07-08, 34-40.

Sebestova, J. (2016). The conflict between strategic method application and theoretical knowledge in small and medium sized companies: the case of the Czech Republic. Business: Theory and Practice, 17(2), 101-108. doi: 10.3846/btp.2016.549

Souchkov, V. (2008). A brief history of TRIZ. Retrieved from http://www.xtrix.com/ BriefHistoryOfTRIZ. pdf

Su, C. T., \& Chou, C. J. (2008). A systematic methodology for the creation of six-sigma projects: A case study of semiconductor foundry. Expert Systems with Applications, 34, 2693-2703. doi: 10.1016/j.eswa.2007.05.014

Swarnakar, V., Vinodh, S., \& Antony, J. (2016). Deploying Lean Six Sigma framework in an automotive component manufacturing organization. International Journal of Lean Six Sigma, 7(3), 267-293. doi: 10.1108/ IJLSS-06-2015-0023

Talapatra, S., Uddin, M. K., \& Rahman, M. H. (2018). Development of an Implementation Framework for Integrated Management System Based on the Philosophy of Total Quality Management. American Journal of Industrial Business Management, 8(6), 1507-1516. doi: 10.4236/ajibm.2018.86101

Tobin, L. M. (1990). The new quality landscape: Total Quality Management. Journal of System Management, 41, 10-14.

Toth, N. (1985). The Oldowan reassessed: A close look at early stone artefacts. Journal of Archaeological Science, 12, 101-120. doi: 10.1016/0305-4403(85)900561

Valles, A., Sanchez, J., Morales, Noriega S., \& Gomez Nunez, B. (2009). Implementation of Six Sigma in a Manufacturing Process: A Case Study. The International Journal of Industrial Engineering: Theory, Applications and Practice, 16, 171-181.

Wedell-Wedellsborg, T. (2017). Are you solving the right problems. Retrieved from https://hbr.org/2017/01/ are-you-solving-the-right-problems

Whitfield, R., \& Kwok, K. (1996). Improving integrated circuits assembly quality - a case study. International Journal of Quality \& Reliability Management, 13(5), 27-39. doi: 10.1108/02656719610118098

Wyper, B., \& Harrison, A. (2000). Deployment of six-sigma methodology in human resource function: a case study. Total Quality Management, 11(4-6), S720S727. doi: 10.1080/09544120050008129

Yang, T., \& Hsieh, C. H. (2009). Six-sigma project selection using national quality award criteria and Delphi fuzzy multiple decision-making method. Expert Systems with Applications, 36, 7594-7603. doi: 10.1016/j. eswa.2008.09.045 